Article

\title{
Research about Organic Matter Removal and Biofilms Development of Pilot-Scale UV/ $\mathrm{H}_{2} \mathrm{O}_{2}$-BAC Process
}

\author{
Wuchang Song ${ }^{1}$, Congcong $\mathrm{Li}^{2}{ }^{2}$, Zhenqi Du ${ }^{1,3}$, Jiangang Yue ${ }^{4}$, Wenjun Sun ${ }^{5}$, Lian Hou ${ }^{1,6}$, Jianguang Liu ${ }^{7}$ * \\ and Ruibao Jia 1 ,*
}

check for updates

Citation: Song, W.; Li, C.; Du, Z.; Yue, J.; Sun, W.; Hou, L.; Liu, J.; Jia, R. Research about Organic Matter Removal and Biofilms Development of Pilot-Scale UV $/ \mathrm{H}_{2} \mathrm{O}_{2}$-BAC Process. Water 2021, 13, 565. https://doi.org/ 10.3390/w13040565

Academic Editor: Marco Guida

Received: 17 January 2021

Accepted: 17 February 2021

Published: 23 February 2021

Publisher's Note: MDPI stays neutral with regard to jurisdictional claims in published maps and institutional affiliations.

Copyright: (c) 2021 by the authors. Licensee MDPI, Basel, Switzerland. This article is an open access article distributed under the terms and conditions of the Creative Commons Attribution (CC BY) license (https:// creativecommons.org/licenses/by/ $4.0 /)$.
1 Institute of Water Treatment, Shandong Province Water Supply and Drainage Monitoring Center, Jinan 250101, China; songwuchang@163.com (W.S.); 2011570@tongji.edu.cn (Z.D.); houla@cae.cn (L.H.)

2 College of Environment, Hohai University, Nanjing 210098, China; licongcong0612@163.com

3 College of Environmental Science and Engineering, Tongji University, Shanghai 200092, China

4 Jinan Hongquan Water Making Co., Ltd., Jinan Water Group Co., Ltd., Jinan 250012, China; wxin163@sina.com

5 School of Evironment, Tsinghua University, Beijing 100084, China; wsun@tsinghua.edu.cn

6 Xi'an High-Tech Institute, Xi'an 710025, China

7 School of Municipal and Environmental Engineering, Shandong Jianzhu University, Jinan 250101, China

* Correspondence: liujgljg@126.com (J.L.); jiaruibao1968@163.com (R.J.); Tel.: +86-531-89017607 (R.J.); Fax: +86-531-89017600 (R.J.)

\begin{abstract}
As a green advanced process for drinking water treatment, the UV/hydrogen peroxide $\left(\mathrm{UV} / \mathrm{H}_{2} \mathrm{O}_{2}\right)$ process has been gradually applied in China. To study the effect and mechanism of organic matter removal and the development of microbial communities in the $\mathrm{UV} / \mathrm{H}_{2} \mathrm{O}_{2}$-biological activated carbon ( $\mathrm{UV} / \mathrm{H}_{2} \mathrm{O}_{2}-\mathrm{BAC}$ ) process, a pilot-scale $\mathrm{UV} / \mathrm{H}_{2} \mathrm{O}_{2}-\mathrm{BAC}$ system was built and operated over one year. Low water temperature affects the $\mathrm{UV} / \mathrm{H}_{2} \mathrm{O}_{2}$ process efficiency, the biofilms in the BAC system were mature and stable after 240 days, and the contribution rate of BAC adsorption to dissolved organic carbon (DOC) removal was approximately $14.2 \%$ after one year of operation. The liquid chromatography-organic carbon detection (LC-OCD) analysis shows that $\mathrm{UV} / \mathrm{H}_{2} \mathrm{O}_{2}$ process can increase the amounts of Low Molecular Weight (LMW) neutrals, and the specific UV absorbance $\left(\mathrm{SUVA}_{254}\right)$ value is not suitable for predicting Trihalomethanes (THMs) precursor contents in water after $\mathrm{UV} / \mathrm{H}_{2} \mathrm{O}_{2}$ treatment. High-throughput sequencing results prove that microbial species in the middle section are the most abundant compared to those in the influent and effluent sections, hydrogen peroxide has lower inhibition on the development of microbial community than ozone and the low concentration of hydrogen peroxide $(<0.25 \mathrm{mg} / \mathrm{L})$ promotes the development of the microbial communities, hydrogen peroxide can reduce Proteobacteria abundance by inhibiting the growth of anaerobes. Acidobacteria may have a certain contribution to the degradation of soil organic matter (SOM), and the effluent section of BAC with low DOC concentration cannot form the dominant species of Rhodobacter.
\end{abstract}

Keywords: drinking water treatment; granular activated carbon; UV-AOPs; biofilm microbial community

\section{Introduction}

With the development of the economy and the improvement of productivity, developing countries are facing more serious problems of surface water pollution, such as eutrophication of water body and toxic organic matter pollution, and source water is gradually micro-polluted, which also increases the difficulty of ensuring the safety of drinking water. Relevant investigation and research showed that the average antibiotic concentration in the middle and lower reaches of the Yangtze River Basin was about 92.95-156 ng/L [1], and the highest concentration of ciprofloxacin in the Yamuna River in India even reached $1440 \mathrm{ng} / \mathrm{L}$ [2]. During the eutrophication period of surface water bodies, the content of 2MIB, a typical odor compound in the source water of eastern China, reached $2000 \mathrm{ng} / \mathrm{L}[3,4]$. 
Conventional treatment processes are inadequate at controlling the levels of organic pollutants in the source water; hence, water quality safety has become an urgent problem to solve. At present, the $\mathrm{O}_{3}$-BAC process is the mainstream advanced treatment process in China [5], the $\mathrm{O}_{3}$-BAC process can effectively remove organic pollutants, but the removal effect of high-concentration odor substances of this process water is not good since the characteristics of selective oxidation of ozone, and it easily causes bromate problems [6]. Therefore, it is necessary to find a more efficient and safe alternative technology.

The $\mathrm{UV} / \mathrm{H}_{2} \mathrm{O}_{2}$ process can effectively remove odor substances in drinking water [7]. Our previous study showed that the $\mathrm{UV} / \mathrm{H}_{2} \mathrm{O}_{2}$-biological activated carbon ( $\mathrm{UV} / \mathrm{H}_{2} \mathrm{O}_{2}$ $\mathrm{BAC}$ ) combined process had higher organic matter removal efficiency and effluent safety than the $\mathrm{O}_{3}$-BAC process [8]. Granular activated carbon (GAC) with large specific surface areas and suitable pore structures demonstrates high adsorption capacities, which can effectively remove the dissolved organic compounds, including biodegradable organic compounds, halogenated hydrocarbons, odor compounds and other pollutants $[8,9]$. With the operation of the GAC system, biofilms are formed on the surface of activated carbon, and GAC gradually changes into BAC, and biodegradation becomes the main reason for organic matter removal $[10,11]$. Identifying the dominant bacteria population composition can increase the understanding of activated carbon filter operations, which will improve the BAC filter designs and maximize the BAC filter application realization. At present, the effect of the influent water quality on the development of microbial populations in BAC filter systems has been reported, such as that DOC and ammonia nitrogen levels could affect the bacterial diversity and community composition in BAC filters [12], and High residual ozone decreased the attached bacterial density and removal of DOC [13]. However, the effect of the effluent water with $\mathrm{H}_{2} \mathrm{O}_{2}$ derived from the $\mathrm{UV} / \mathrm{H}_{2} \mathrm{O}_{2}$ process on the BAC filter systems requires additional investigation, and most studies mainly focused on the effect of the water quality derived from the ozone-oxidized effluent on the population structure of the BAC filter [14-16], while the effect of residual $\mathrm{H}_{2} \mathrm{O}_{2}$ from the $\mathrm{UV} / \mathrm{H}_{2} \mathrm{O}_{2}$ process on the BAC filter microorganism was neglected. Furthermore, most experimental studies were limited to laboratory-scale and short-term research, and few studies regarding the removal efficiency of organic matter and microbial communities with different carbon layer depths in the pilot-scale $\mathrm{UV} / \mathrm{H}_{2} \mathrm{O}_{2}-\mathrm{BAC}$ combined process have been published.

To solve these problems, a pilot-scale UV $/ \mathrm{H}_{2} \mathrm{O}_{2}$-BAC process was built. The organic matter removal efficiency was studied, and liquid chromatography-organic carbon detection (LC-OCD) was used to analyze the changes of organic matters during the $\mathrm{UV} / \mathrm{H}_{2} \mathrm{O}_{2}$ BAC process. Meanwhile, the development of biofilms in the activated carbon was studied. The structure and abundance of microbial communities at different carbon depths were compared through high-throughput sequencing. The effect of different doses of $\mathrm{H}_{2} \mathrm{O}_{2}$ on the development of microbial communities was obtained, which contributes to the better application of the $\mathrm{UV} / \mathrm{H}_{2} \mathrm{O}_{2}-\mathrm{BAC}$ process in actual water treatment.

\section{Materials and Methods}

\subsection{Experimental Setup and Operating Conditions}

The pilot plants were located in the Quehua Water Plant, which takes water directly from the Yellow river reservoir. The process flowrate of the $U V / \mathrm{H}_{2} \mathrm{O}_{2}$ process was $5 \mathrm{~m}^{3} / \mathrm{h}$. The UV/ $\mathrm{H}_{2} \mathrm{O}_{2}$ system was provided by Trojan, and the UV system consists of four $500 \mathrm{~W}$ low-voltage UV-C lamps, and the theoretical UV dose is $350 \mathrm{~mJ} / \mathrm{cm}^{2}$. The process flow diagram is shown in Figure 1. The operation mode of the activated carbon column was upward flow, the diameter of the activated carbon column was $20 \mathrm{~cm}$, the process flowrate was $80 \mathrm{~L} / \mathrm{h}$, the empty bed contact time (EBCT) was $10.6 \mathrm{~min}$, the filling height was 180 $\mathrm{cm}$, and the height of the supporting layer was $20 \mathrm{~cm}$. The used carbon was coconut shell activated carbon, the parameters are shown in Table S1, and the influent water quality indices of BAC are shown in Table 1. 


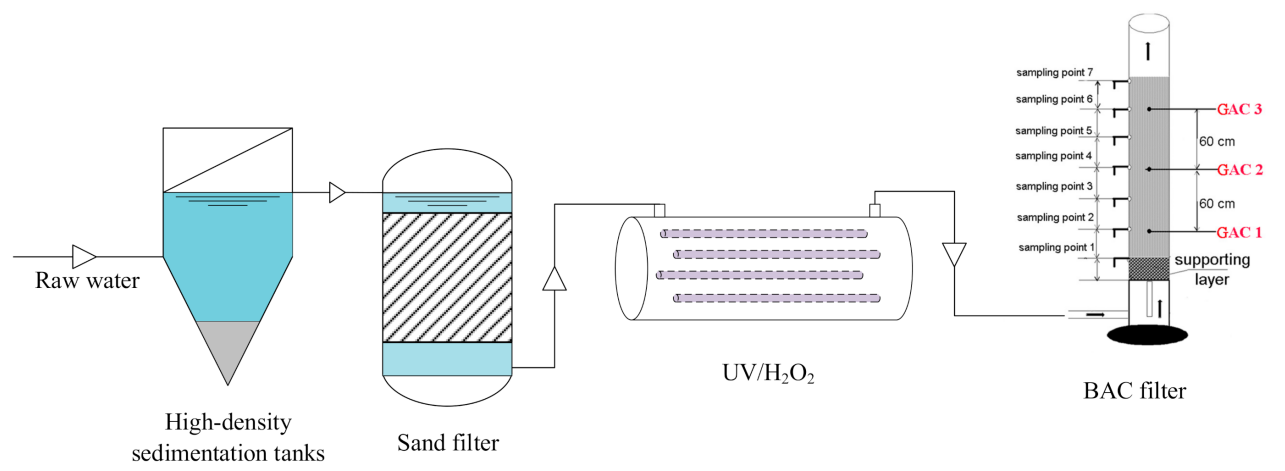

Figure 1. Process flow and structural of $\mathrm{UV} / \mathrm{H}_{2} \mathrm{O}_{2}$-biological activated carbon $\left(\mathrm{UV} / \mathrm{H}_{2} \mathrm{O}_{2}-\mathrm{BAC}\right)$.

Table 1. Characteristics of BAC influent.

\begin{tabular}{|c|c|c|c|c|c|c|c|c|c|}
\hline $\begin{array}{l}\text { Temp } \\
\left({ }^{\circ} \mathrm{C}\right)\end{array}$ & $\begin{array}{l}\text { Turbidity } \\
\text { (NTU) }\end{array}$ & $\mathrm{pH}$ & $\begin{array}{l}\mathrm{UV}_{254} \\
\left(\mathrm{~cm}^{-1}\right)\end{array}$ & $\begin{array}{c}\text { DOC } \\
(\mathrm{mg} / \mathrm{L})\end{array}$ & $\begin{array}{c}\mathrm{NH}_{4}{ }^{+}-\mathrm{N} \\
(\mathrm{mg} / \mathrm{L})\end{array}$ & $\begin{array}{c}\mathrm{H}_{2} \mathrm{O}_{2} \\
(\mathrm{mg} / \mathrm{L})\end{array}$ & $\begin{array}{c}\text { DO } \\
(\mathrm{mg} / \mathrm{L})\end{array}$ & $\begin{array}{c}\mathrm{Br}^{-} \\
\text {(ug/L) }\end{array}$ & $\begin{array}{c}\mathrm{I}^{-} \\
(\mathrm{ug} / \mathrm{L})\end{array}$ \\
\hline $10-22$ & $0.80-2.15$ & $8.0-8.3$ & $0.21-0.28$ & $2.69-3.35$ & $0.41-0.53$ & $5-6.5$ & $4.0-5.0$ & $243-262$ & 14-17 \\
\hline
\end{tabular}

\subsection{Experimental Analysis Methods}

\subsubsection{Conventional Index}

The conventional indices for detection are the DOC, $\mathrm{UV}_{254}, \mathrm{H}_{2} \mathrm{O}_{2}$ content, specific surface area (SBET), molecular weight distribution and phospholipid biomass. The detection methods are listed in Table 2.

Table 2. Conventional indexes detecting methods or instruments.

\begin{tabular}{ccc}
\hline Number & Detection Index & Determination Method \\
\hline 1 & DOC & Shimazu TOC analyzer \\
2 & $\mathrm{DO}$ & Thermo Orion 3star DO analyzer \\
3 & $\mathrm{UV}_{254}$ & Ultraviolet spectrophotometry \\
4 & $\mathrm{H}_{2} \mathrm{O}_{2}$ content & Spectrophotometry \\
5 & SBET & AUTOSORB 6b analyzer \\
6 & Molecular weight distribution & Ultrafiltration-TOC analyzer \\
7 & Phospholipid biomass & Phosphatide method [17] \\
\hline
\end{tabular}

\subsubsection{LC-OCD Scanning}

The principle of LC-OCD is to separate organics according to molecular weight using size exclusion chromatography and subsequently analyze them by $\mathrm{OCD}$, ultraviolet detector (UVD)and OND detector. The organics in water can be divided into biopolymers, humic acid, building blocks, acid and LMW humics, LMW neutral $[18,19]$.

The detection conditions of LC-OCD were as follows: The instrument model is LCOCD-Model 9. The chromatographic column is a polymethacrylate-based weak cation exchange column, the sample volume was $1000 \mathrm{uL}$, the total running time of each sample was $70 \mathrm{~min}$, and the experimental results were obtained by peak integration with specific software.

\subsubsection{High-Throughput Sequencing and Parameter Analysis}

The carbon samples were taken at depths of $30 \mathrm{~cm}$ (GAC 1), $90 \mathrm{~cm}$ (GAC 2), and $150 \mathrm{~cm}$ (GAC 3) from the water influent end of the activated carbon layer, each position was sampled three times in parallel to reduce the errors. According to the Illumina Miseq highthroughput sequencing requirements, bidirectional sequencing was performed to design the target region with a " 5 " Miseq linker. Using a two-step PCR amplification method, first, a specific primer (hereafter described as an inner primer) was used to amplify the 
target fragment, which was subjected to gel recovery with the recovered product used as a template for secondary PCR amplification. The specific detection steps and the calculation of Chao 1, Shannon and Simpson indexes can refer to the research of Zhang [20].

\section{Results and Discussion}

\subsection{Organic Matter Removal by $\mathrm{UV} / \mathrm{H}_{2} \mathrm{O}_{2}-B A C$ Process}

Figure 2 shows the variations and removal rates of the DOC concentration at the influent and effluent areas of the $\mathrm{UV} / \mathrm{H}_{2} \mathrm{O}_{2}$-BAC process. After the $\mathrm{UV} / \mathrm{H}_{2} \mathrm{O}_{2}$ process oxidation, the average DOC value was reduced from $4 \mathrm{mg} / \mathrm{L}$ (influent) to $3 \mathrm{mg} / \mathrm{L}$ (effluent), and the DOC value of the activated carbon filter effluent water was maintained at an average low level of $1.2 \mathrm{mg} / \mathrm{L}$. By analyzing the change trend of the DOC removal rate in the $\mathrm{UV} / \mathrm{H}_{2} \mathrm{O}_{2}$ process, we observe that the DOC removal rate in winter (December-February) has a significant downward trend. This trend was interesting because the temperature coefficient of most photochemical reactions was close to 1 , the removal efficiency of organic matter by the $\mathrm{UV} / \mathrm{H}_{2} \mathrm{O}_{2}$ process generally does not change with the change in temperature $[21,22]$, and DOC is not a gas-phase organic matter and does not involve heterogeneous mass transfer process. We speculate that water temperature affects the UV output efficiency of mercury lamps, which reduces photon production [23]. The result of the $\mathrm{H}_{2} \mathrm{O}_{2}$ ratios also supports this speculation (Figure S1). According to Einstein's law of photochemical equivalence, since the absorption of photons by molecules is a single-photon process, the reduction of photon production will reduce the generation of hydroxyl radicals, so the removal rate of DOC will be reduced.
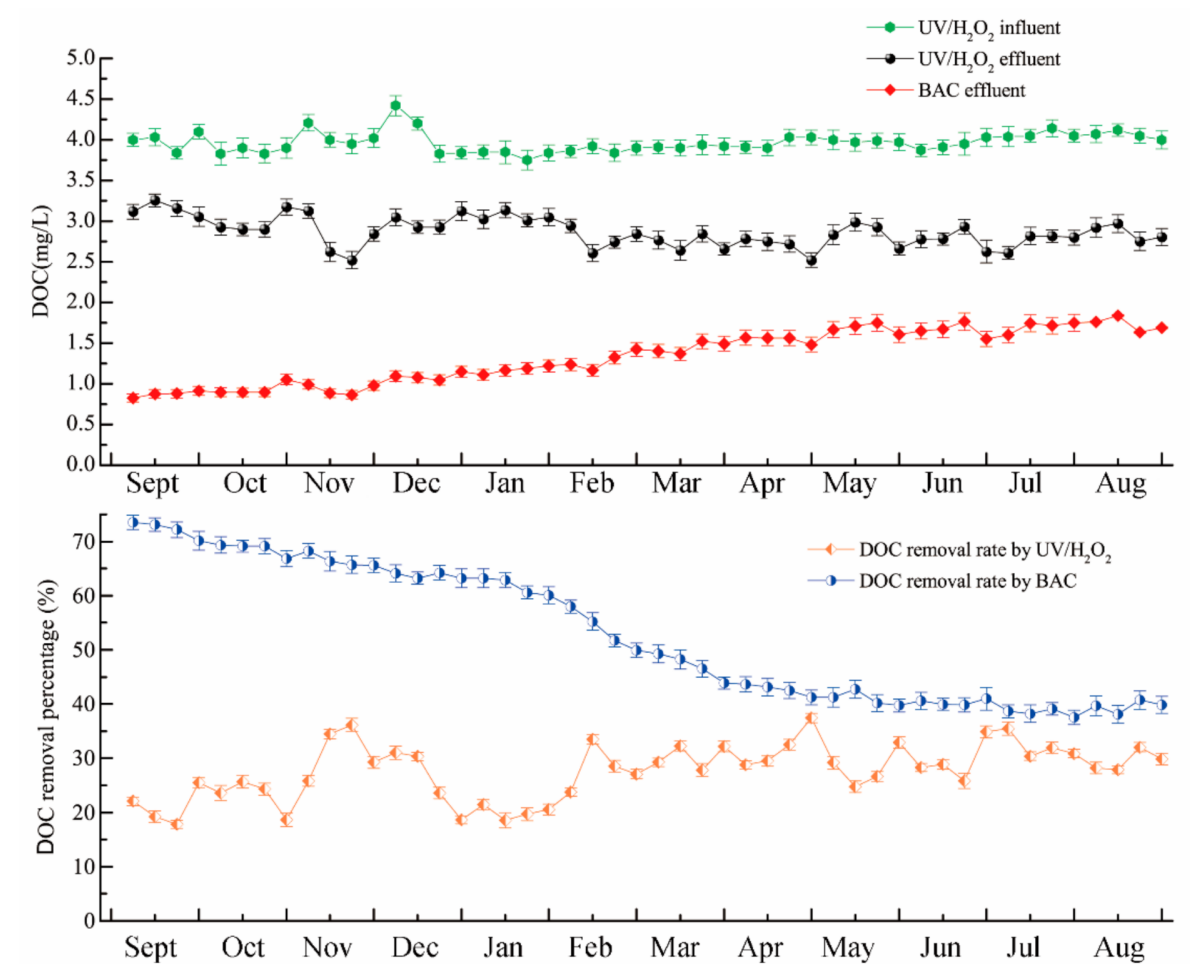

Figure 2. Dissolved organic carbon (DOC) removal of $\mathrm{UV} / \mathrm{H}_{2} \mathrm{O}_{2}-\mathrm{BAC}$ process.

In the initial stage of the process operation, the removal of DOC by the activated carbon filter maintained a high efficiency with an average removal rate of approximately $70 \%$. The high DOC removal rate was directly attributed to the adsorption of the activated carbons. Afterwards, when the adsorption capacity of activated carbon tends to be saturated, the biofilms on the surface of activated carbon gradually forms and BAC gradually transits to GAC; the DOC value removal rate gradually decreased and finally maintained at approximately $38.1 \%$. Compared with pilot-scale $\mathrm{O}_{3}-\mathrm{BAC}, \mathrm{UV} / \mathrm{H}_{2} \mathrm{O}_{2}-\mathrm{BAC}$ has a higher 
organic matter removal efficiency. Ross et al. showed that the DOC removal rate by BAC in the stable operation stage of the $\mathrm{O}_{3}$-BAC process was approximately $24 \%$ [24]. Our research group also conducted a pilot test on the $\mathrm{O}_{3}$-BAC process using the same pretreatment equipment, and the results showed that the removal rate of BAC to DOC in the stable stage was approximately $34 \pm 2 \%$ [25].

Figure 3 shows the specific surface area change of the activated carbons as a function of the carbon depths. The specific surface area can reflect the adsorption capacity of the activated carbon filter and subsequently explain the high DOC removal efficiency of the activated carbon filter from the physical viewpoint. $\mathrm{S}_{\mathrm{BET}}$ decreases from $974 \mathrm{~m}^{2} / \mathrm{g}$ initially to $704 \mathrm{~m}^{2} / \mathrm{g}$ (GAC 1), $717 \mathrm{~m}^{2} / \mathrm{g}$ (GAC 2), and $730 \mathrm{~m}^{2} / \mathrm{g}$ (GAC 3) during operation, respectively. The decrease in SBET value at the influent section (GAC 1) occurred earlier than that at the middle section (GAC 2) and effluent section (GAC 3). After 240 days of operation, the SBET value tended to stabilize, which was similar to the change trend of the BAC removal rate of DOC in Figure 2, indicating that the high efficiency of the BAC removal of DOC in the early stage of system operation may be attributed to adsorption. When the adsorption capacity of activated carbon tends to be saturated, the removal rate of DOC also tends to be stable. At this stage, biodegradation was the main reason for the removal of organic matter by activated carbon columns. Liang's mathematical model showed that the efficiency of biodegradation to DOC removal in BAC at this stage accounted for approximately $88 \%$ [26]. Our previous study showed that the average DOC removal rate of the same activated carbon column was approximately $38.1 \%$ and $32.7 \%$ after continuous operation for one year and five years, respectively [8]. Since the biofilms on the activated carbons had been stabled after one year of operation, it was assumed that the decrease in DOC removal rate was due to the decrease in adsorption capacity, and we assumed that the adsorption capacity of BAC has reached the limit after 5 years of operation; then, the calculated contribution rate of adsorption to the DOC removal in the activated carbon column after one year of operation was approximately $\eta=\frac{(38.1 \%-32.7 \%)}{38.1 \%}=14.2 \%$, and the biodegradation efficiency was approximately $85.8 \%$, which was in agreement with the conclusion of Liang et al.

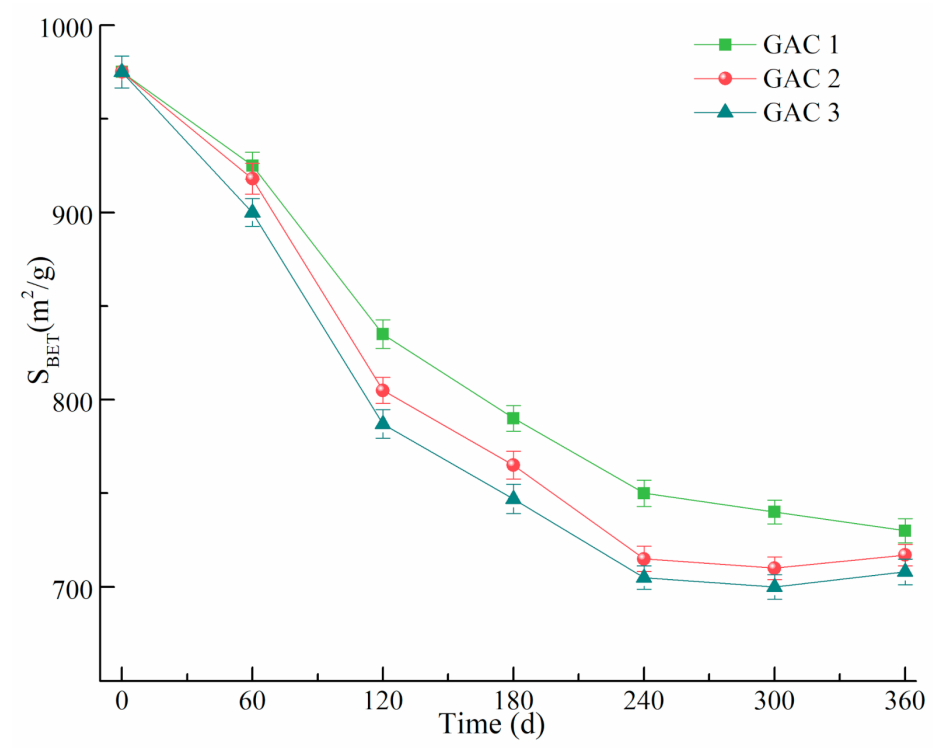

Figure 3. Specific surface area of granular activated carbon (GAC) in different carbon layers.

\subsection{Organics Transform Analysis of $U V / \mathrm{H}_{2} \mathrm{O}_{2}$-BAC Process \\ 3.2.1. Change of Molecular Weights of Organic Matters}

Figure 4 shows the change in molecular weight distribution in the $\mathrm{UV} / \mathrm{H}_{2} \mathrm{O}_{2}-\mathrm{BAC}$ process. Compared with the $\mathrm{BAC}$ process, the $\mathrm{UV} / \mathrm{H}_{2} \mathrm{O}_{2}$ process had lower DOC value removal efficiency, which was determined by the characteristics of the $\mathrm{UV} / \mathrm{H}_{2} \mathrm{O}_{2}$ process. 
Previous studies had also shown that the simple advance oxidation process was difficult to have a good mineralization effect on organics $[27,28]$, but the $\mathrm{UV} / \mathrm{H}_{2} \mathrm{O}_{2}$ process can decompose macromolecular organics in raw water into micromolecular organics, which promotes the subsequent removal of organics by the BAC process $[8,29]$. In Figure 4 , the removal rate of organics with a molecular weight greater than $30 \mathrm{kDa}$ by the $\mathrm{UV} / \mathrm{H}_{2} \mathrm{O}_{2}$ process was approximately $50 \%$, and the DOC values of small-molecule organics did not decrease significantly, which indicated that hydroxyl radical can oxidize macromolecular organics into small molecules or double-bond organics. The activated carbon filter had a better removal effect on small molecular organics $(<3 \mathrm{kDa})$ with a removal rate of over $70 \%$.

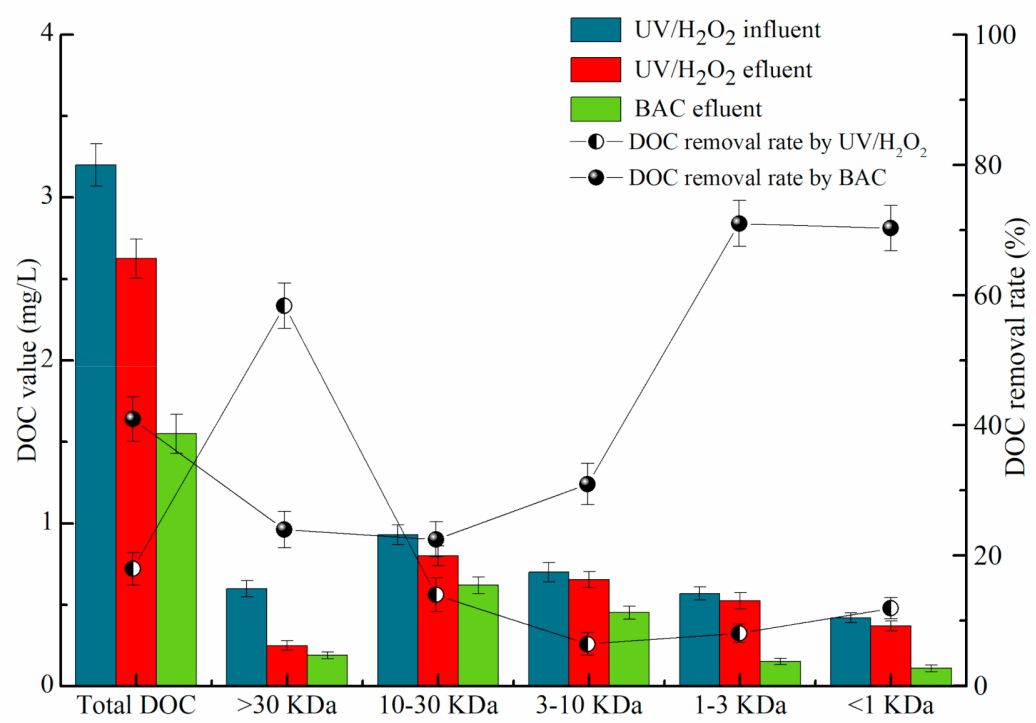

Figure 4. Change of molecular weights distribution of $\mathrm{UV} / \mathrm{H}_{2} \mathrm{O}_{2}-\mathrm{BAC}$ process.

\subsubsection{LC-OCD-OND Fractionation Analysis}

LC-OCD-OND was used to scan the influent and effluent water of the process, and the results are shown in Figure 5. The peaks A, B, C, D and E of the black curves represent biopolymers, humic, building blocks, LMW acids and LMW neutrals respectively. The molecular weights decrease in turn, and the blue curves were the $\mathrm{UV}_{254}$ response value of each component. It can be seen from Figure 5 that the peak areas of biopolymers and humic decreased significantly after the $\mathrm{UV} / \mathrm{H}_{2} \mathrm{O}_{2}$ process, the peak areas of building blocks, LMW acids and LMW neutrals with smaller molecular weights increased, which also confirmed the fragmentation effect of advanced oxidation on macromolecular components. The response values of $\mathrm{UV}_{254}$ decreased after advanced oxidation, which indicated that advanced oxidation had good degradation effect on aromatic organic compounds; the results of quantitative analysis (Table 3) also showed that $\mathrm{SUVA}_{254}$ value decreased from 2.19 to 1.02 after $\mathrm{UV} / \mathrm{H}_{2} \mathrm{O}_{2}$ process. Although Marais proved that there is a positive correlation between the number of Trihalomethanes (THMs) precursors and $\mathrm{SUVA}_{254}$ values in natural water [30], our detection results showed that the content of THMs and haloacetic acid (HAA) precursor increases after $\mathrm{UV} / \mathrm{H}_{2} \mathrm{O}_{2}$ process (Table S2). This indicates that the $\mathrm{SUVA}_{254}$ value is not suitable for characterizing DBP precursors in water after advanced oxidation treatment; another possible reason was that the $\mathrm{SUVA}_{254}$ value of natural water involved in this study is low, and some studies have shown that there is no good linear relationship between $\mathrm{SUVA}_{254}$ value and the content of THMs precursors in low $\mathrm{SUVA}_{254}$ water [30,31]. 


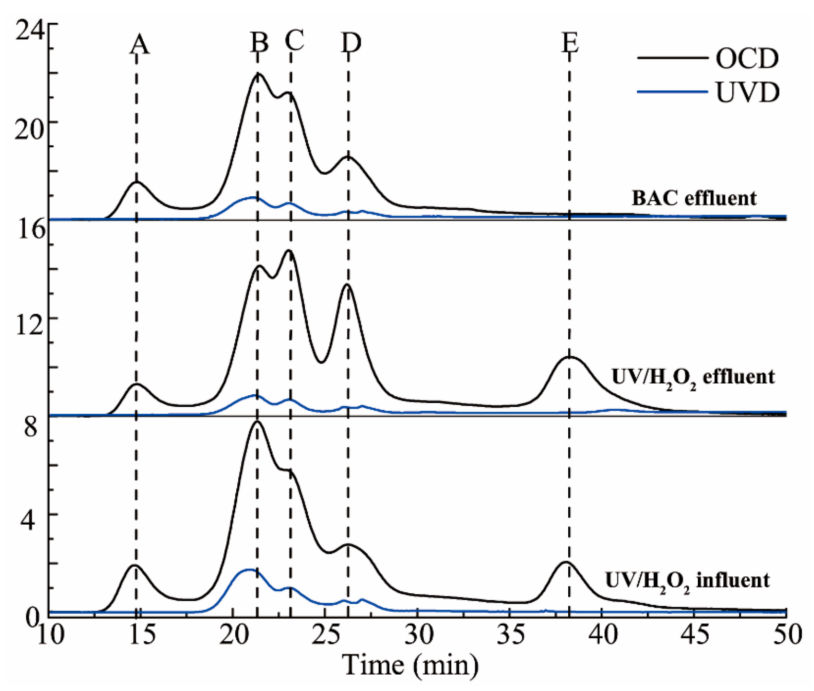

Figure 5. Variation tendency of organic carbon detection (OCD) and UVD signals.

Table 3. Results of liquid chromatography-organic carbon detection (LC-OCD) fractionation.

\begin{tabular}{ccccccc}
\hline & \multicolumn{2}{c}{ Humic } & & \multicolumn{2}{c}{ Biopolymers } \\
\cline { 2 - 3 } & DON(mg/L) & Mol.-Weight(Mn) & & SOM(mg/L) & \% \\
\cline { 3 - 4 }$/ \mathrm{H}_{2} \mathrm{O}_{2}$ influent & 0.1 & 445 & 2.19 & 0.328 & $100 \%$ \\
$\mathrm{UV} / \mathrm{H}_{2} \mathrm{O}_{2}$ effluent & 0.069 & 355 & 1.02 & 0.259 & $90 \%$ \\
$\mathrm{BAC}$ effluent & 0.072 & 403 & 1.53 & $<1$ & $100 \%$ \\
\hline
\end{tabular}

The quantitative analysis of LC-OCD scanning results is shown in Tables 3 and 4 . After UV $/ \mathrm{H}_{2} \mathrm{O}_{2}$ oxidation, the biopolymer content reduced $33.9 \%$, and the proportion of protein in biopolymers reduced from $100 \%$ to $90 \%$, which also confirms the degradation effect of hydroxyl radicals on protein organics with larger molecular weight [28]. After advanced oxidation, the content of LMW neutrals increased by $16 \%$, but decreased by $56.3 \%$ by the BAC system, which also confirmed the conclusion in Section 3.2.1. Table 4 shows that BAC has a good removal effect on DON, and it was speculated that BAC also has a good control effect on the nitrogenous disinfection by-product (N-DBP) precursor, which was confirmed by Zheng et al. [32].

Table 4. DOC value of each component.

\begin{tabular}{cccccc}
\hline & Biopolymers & Humic & Building Blocks & LMW-Acids & LMW-Neutrals \\
\hline $\mathrm{UV} / \mathrm{H}_{2} \mathrm{O}_{2}$ influent & $0.59(16)$ & $1.82(50)$ & $0.51(14)$ & $0(0)$ & $0.75(20)$ \\
$\mathrm{UV} / \mathrm{H}_{2} \mathrm{O}_{2}$ effluent & $0.39(11.5)$ & $1.56(46.2)$ & $0.53(15.7)$ & $0.03(1)$ & $0.87(25.7)$ \\
$\mathrm{BAC}$ effluent & $0.31(17)$ & $1.32(54)$ & $0.40(15)$ & $0(0)$ & $0.38(14)$
\end{tabular}

Note: the italics in brackets indicate the proportion (\%) of each component to total DOC value, and the units of $\mathrm{DOC}$ value is $\mathrm{mg} / \mathrm{L}$.

\subsection{Analysis of Biofilms in Activated Carbons}

\subsubsection{Changes of Biomass Concentration and Inner DOC Removal Rate of Activated Carbon}

The biomass on the surfaces of activated carbons at different times and depths of carbon layers was measured by the phospholipid method. The results are shown in Figure 6a. The growth rate of biomass at the influent section of the activated carbon column was the fastest, since the influent section can absorb more organic matters, and the growth of microorganisms is basically not limited by nutrients and shows an exponential growth trend, since the decomposition of $\mathrm{H}_{2} \mathrm{O}_{2}$ will produce $\mathrm{O}_{2}$, which increases the DO concentration $(10.5 \mathrm{mg} / \mathrm{L})$ in the influent section, the growth of microorganisms is also not limited by DO concentration. The adsorption of activated carbon on organic matters was 
shown as a decrease in DOC value. In Figure $6 b$, at the initial stage of operation, when the depth of the carbon layer increased, the DOC value significantly decreased. The lack of nutrients caused the biomass growth rate of the middle section and effluent section to be lower than that of the influent section, which results in vertical stratification.
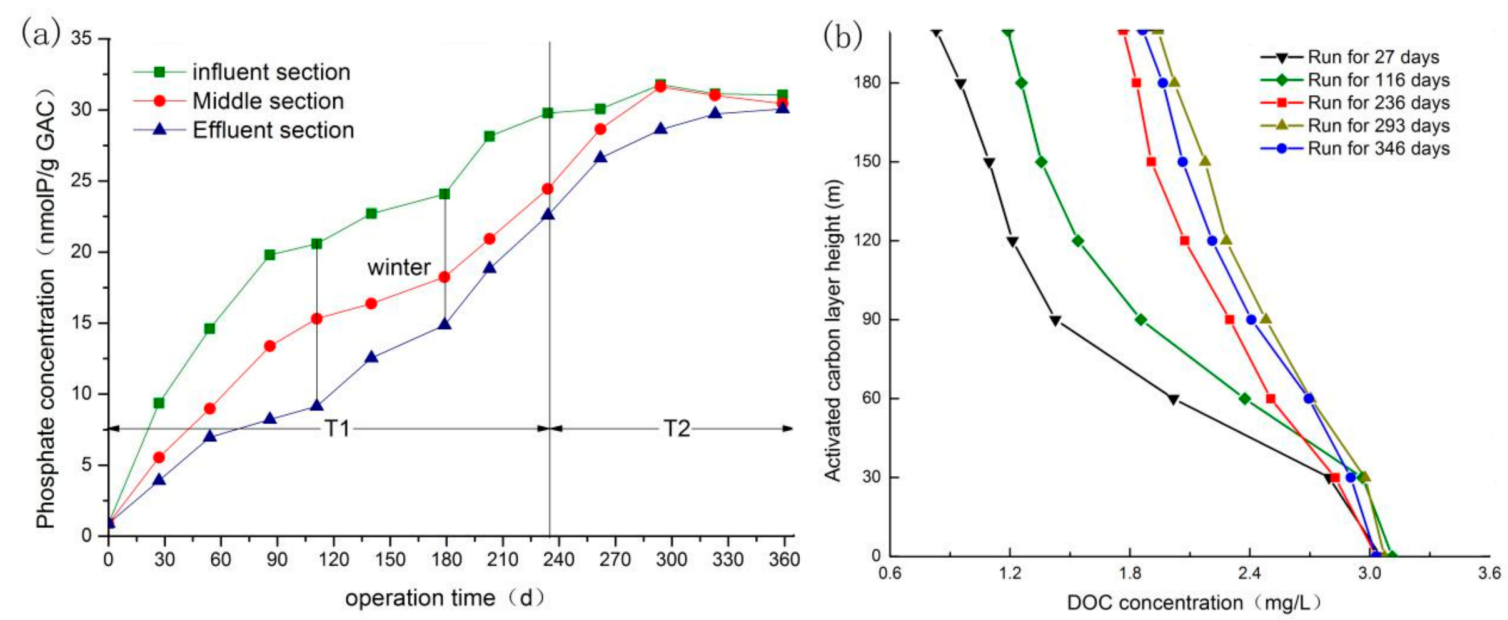

Figure 6. (a) Biomass change of carbon surfaces with different carbon depths (GAC $1=30 \mathrm{~cm}, \mathrm{GAC} 2=90 \mathrm{~cm}, \mathrm{GAC} 3=150 \mathrm{~cm}$ ); (b) DOC removal rates in the BAC (27 days, 116 days, 236 days and 346 days).

In addition, Figure 6a shows that the growth rate of biomass in the influent and middle sections in winter decreased, while the increase in biomass in the effluent section is faster than that in the influent and middle sections. The reason was that the activity of microorganisms was reduced under low-temperature conditions, which reduced the degradation of microorganisms on organic matters [25]. In addition, the organic matter in water easily combines into macromolecular organic matter under low-temperature conditions, which increased the difficulty of adsorption and removal [33]. Therefore, the content of organic matters in the effluent section increased and the growth rate of biomass accelerated.

From the perspective of time change, the biofilms rapidly accumulated in the T1 stage (the first 240 days) and subsequently gradually stabilized, and the vertical stratification in the activated carbon column gradually disappeared after 293 days. Compared with other research results, the biofilms on the surface of the activated carbon column had longer mature and stable time. Oriol's study on BAC showed that the stable biofilms were formed after 180 days of operation, and the vertical stratification disappeared after 280 days [34]. This difference may be attributed to the temperature difference of water. The experiment was run in the local winter from 120 to 180 days, and the water temperature was $2.5-5{ }^{\circ} \mathrm{C}$. The temperature reduced the metabolism of microorganisms, led to the decrease in the utilization rate of microorganisms and nutrients in the biofilm, and inhibited the growth of biofilms [35].

\subsubsection{Microbial Richness and Diversity}

To further identify and analyze the growth characteristics of activated carbon bed biofilms, a Roche 454 high-flux sequencing system was applied to analyze the microbial community of the activated carbon biofilm, and the results are shown in Table 5. The optimized sequence numbers of the three samples were 30,515 (GAC 1), 31,935 (GAC 2), and 29,917 (GAC 3), and the coverage rate of all samples was $>99 \%$. Three samples were divided into 1160 (GAC 1), 1215 (GAC 2) and 1181 (GAC 3) OTUs with a difference of 3\%, and the theoretical maximum OTU values calculated through Chao 1 theory were 1570 (GAC 1), 1612 (GAC 2) and 1594 (GAC 3), the above data showed that in the up-flow $\mathrm{UV} / \mathrm{H}_{2} \mathrm{O}_{2}-\mathrm{BAC}$ process, the microbial species were more abundant in the middle section than in the influent and effluent sections. This finding may be related to the up-flow 
operation mode. The larger flow shear force in the influent section was not conducive to the formation of thicker biofilms. Silvana's study also showed that the highest biomass accumulation on the surfaces of activated carbons in the activated carbon pool was in the middle section [36]. In addition, the low concentration of $\mathrm{H}_{2} \mathrm{O}_{2}(0.20-0.25 \mathrm{mg} / \mathrm{L})$ in the middle section can promote the development of microbial communities [37], the analysis of the Simpson index and Shannon index showed that the biodiversity in the middle section and effluent section was significantly higher than that in the influent section. Hence, we speculate that the environment with a high concentration of $\mathrm{H}_{2} \mathrm{O}_{2}(5.0-6.0 \mathrm{mg} / \mathrm{L})$ in the influent section has a "screening" effect, which reduces the biodiversity.

Table 5. Diversity estimators of microbial communities in GAC 1, GAC 2 and GAC $3(\alpha=0.03)$.

\begin{tabular}{ccccccc}
\hline Sample & OTUs & Chao 1 & ACE & Shannon & Simpson & Coverage \\
\hline GAC 3 & 1181 & 1594 & 1265.32 & 5.79 & 0.77 & $99.1 \%$ \\
GAC 2 & 1215 & 1612 & 1295.44 & 5.80 & 0.73 & $99.2 \%$ \\
GAC 1 & 1160 & 1570 & 1210.12 & 5.90 & 0.61 & $99.3 \%$ \\
O $_{3}$-BAC-1 & 291 & - & - & 4.39 & 0.757 & - \\
O $_{3}$-BAC-2 & 282 & - & - & 4.57 & 0.821 & - \\
\hline
\end{tabular}

Note: $\mathrm{O}_{3}$-BAC-1 was middle section, $\mathrm{O}_{3}$-BAC-2 was effulent section.

Our previous collaborator Han had used the identical retreatment process to study the microbial community on the surface of activated carbon in the $\mathrm{O}_{3}$-BAC system, by comparing with his results (Table 5), we found that the Shannon index and OTUs of the microbial community affected by $\mathrm{H}_{2} \mathrm{O}_{2}$ were higher than that affected by $\mathrm{O}_{3}$ in the identicalparticle-size activated carbons [5], which indicated that $\mathrm{H}_{2} \mathrm{O}_{2}$ had lower inhibition on the development of the microbial community than ozone.

\subsubsection{Comparison of Biological Community Structures}

Figure 7 shows the microbial composition and clustering relationship of the three samples at the phylum level. There was a correlation between the microbial populations in the middle section and effluent section. The dominant species in the three samples were Proteobacteria, Planktonella, Acidobacteria, Chloroflexi, Actinobacteria and Bacteroidetes. Previous studies have confirmed the correlation between Proteobacteria and organic matter removal, and Proteobacteria also had an important contribution to denitrification [38]. Its content sequence was GAC $3>$ GAC $2>$ GAC 1; since the $\mathrm{H}_{2} \mathrm{O}_{2}$ content decreases with the increase in carbon layer depth, the effluent section has basically no $\mathrm{H}_{2} \mathrm{O}_{2}$, so the existence of $\mathrm{H}_{2} \mathrm{O}_{2}$ may have an inhibitory effect on Proteobacteria. Wang et al. showed that anaerobes were sensitive to $\mathrm{H}_{2} \mathrm{O}_{2}$, and the presence of $\mathrm{H}_{2} \mathrm{O}_{2}$ limited their growth [37]. Therefore, $\mathrm{H}_{2} \mathrm{O}_{2}$ can reduce their abundance by inhibiting the growth of anaerobes in Proteobacteria. Chloroflexi was detected as the dominant bacteria on the activated carbon biofilm and principally responsible for the degradation of carbohydrates and cellular substances [39]. As the concentration of nutrients in the activated carbon filter gradually decreased, the richness of Chloroflexi along the profile exhibited a gradual decrease. Acidobacteria is a type of acidophilic bacteria with high content in soil [40]. Combined with the LC-OCD analysis, we can speculate that it contributes to the degradation of SOM by BAC. In addition, Acidobacteria, which can degrade $\mathrm{H}_{2} \mathrm{O}_{2}$, has a relatively high content in the influent section.

Figure 8 mainly depicts the relative abundancies of the main genus level of GAC 1, GAC 2, and GAC 3. Compared with the $\mathrm{O}_{3}$-BAC process in our previous study [25], there was a significant difference in genus level. The main genus of the $\mathrm{O}_{3}$-BAC filter was Nevskia, Flavobacterium, Acidovorax, Methylomicrobium and Pseudomonas. In the $\mathrm{UV} / \mathrm{H}_{2} \mathrm{O}_{2}-\mathrm{BAC}$ process, the main genera of the activated carbon filters were Gemmata, Gaiella, Leptospirillum, Pirellula, and Planctomyces. Nitrospira is a nitrifying bacteria, which can oxidize nitrite to nitrate [41]. In Figure 8, the Nitrospira content in GAC 1 was significantly higher than those in GAC 2 and GAC 3, and we speculated that nitrification mainly occurs in the influent section of BAC. Rhodoplanes, a genus of Proteus, was an anaerobe [42]. Its 
content sequence was GAC $3>$ GAC $2>$ GAC 1 , which also proved the inhibition of $\mathrm{H}_{2} \mathrm{O}_{2}$ on Proteobacteria. Rhodobacter is an important participant in the degradation of organic pollutants in water [43], and its abundance order was GAC $1>$ GAC $2>$ GAC 3, which implies that the abundance of Rhodobacter was positively related to the concentration of organic matters in the water environment. The effluent section with low DOC concentration cannot form the dominant species of Rhodobacter. Similar rules can be observed from the analysis of microbial communities of activated carbon with different carbon ages. Rhodobacter dominant species can be formed in the aged carbon (6 years) with a relatively high organic matter content in the effluent but not in new carbon [8].

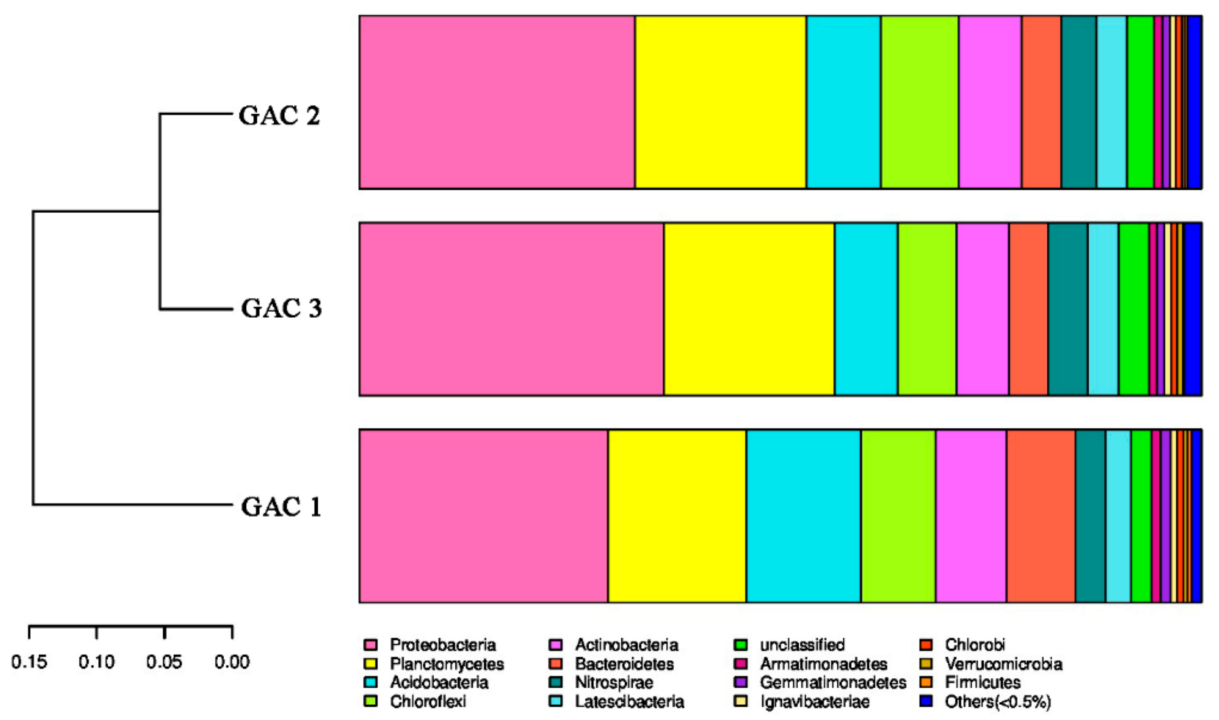

Figure 7. Microbial population classification of activated carbons from different carbon depths (phylum-level).

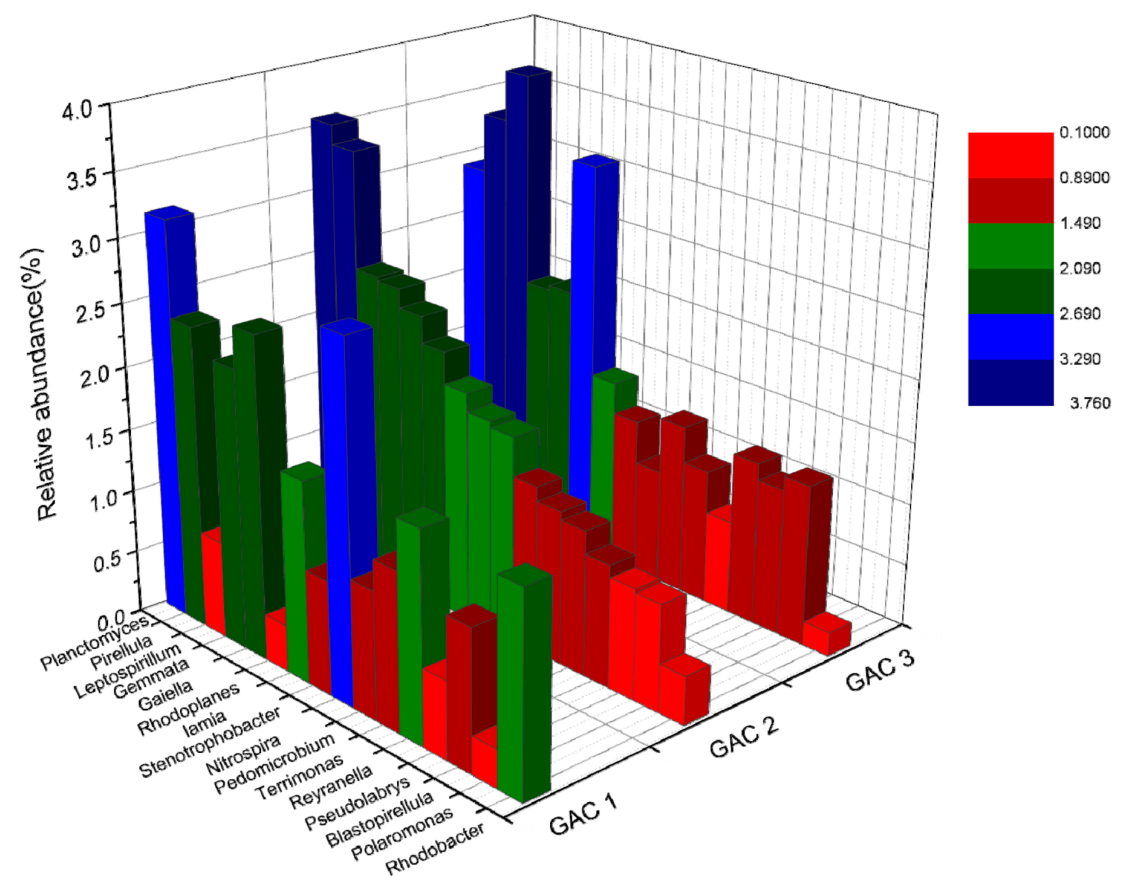

Figure 8. Microbial population classification of activated carbons from different carbon depths (class-level). 


\section{Conclusions}

In this work, the organic matter removal and microbial development of the $\mathrm{UV} / \mathrm{H}_{2} \mathrm{O}_{2}$ $\mathrm{BAC}$ process were studied in detail. The results showed that water temperature reduces the efficiency of the $\mathrm{UV} / \mathrm{H}_{2} \mathrm{O}_{2}$ process by affecting the photon production, and the calculated contribution rate of adsorption to the DOC removal in BAC after one year of operation was approximately $14.2 \% ; \mathrm{UV} / \mathrm{H}_{2} \mathrm{O}_{2}$ process can increase the amounts LMW-neutrals, and $\mathrm{SUVA}_{254}$ value is not suitable for characterizing DBP precursors in water after advanced oxidation treatment, and BAC has a good removal effect on SOM. The growth rate of biomass at the influent section of the activated carbon column was the fastest. Microbial species were more abundant in the middle section than in the influent section and effluent section. The high concentration of $\mathrm{H}_{2} \mathrm{O}_{2}(5-6 \mathrm{mg} / \mathrm{L})$ in the influent section has a "screening" effect, which reduces the biodiversity, and a low concentration of $\mathrm{H}_{2} \mathrm{O}_{2}(<0.25 \mathrm{mg} / \mathrm{L})$ promotes the development of the microbial communities. Shannon index shows that $\mathrm{H}_{2} \mathrm{O}_{2}$ had lower inhibition on the development of microbial community than ozone. $\mathrm{H}_{2} \mathrm{O}_{2}$ can reduce the Proteobacteria abundance by inhibiting the growth of anaerobes, Acidobacteria may contribute to the degradation of SOM, Nitrification mainly occurs in the influent section of BAC. The effluent section of BAC with low DOC concentration cannot form the dominant species of Rhodobacter.

Supplementary Materials: The following are available online at https://www.mdpi.com/2073-444 1/13/4/565/s1, Figure $\mathrm{S1}: \mathrm{H}_{2} \mathrm{O}_{2}$ utilization rate by $\mathrm{UV} / \mathrm{H}_{2} \mathrm{O}_{2}$ process, Table S1: characteristics of the activated carbons, Table S2: the contents of THMs and HAAs precursor during $\mathrm{UV} / \mathrm{H}_{2} \mathrm{O}_{2}$ process.

Author Contributions: Project administration, L.H. and R.J.; Resources, J.Y.; Writing-original draft, W.S. (Wuchang Song); Writing-review \& editing, C.L., Z.D., W.S. (Wenjun Sun) and J.L. All authors have read and agreed to the published version of the manuscript.

Funding: This research was funded by the National Major Science and Technology Projects: Evaluation and standardization for material and equipment of water supply system, grant number 2017ZX07501003; Evaluation and standardization of key technologies in operation and management of urban water supply system, grant number:2017ZX07501002; Special funds for postdoctoral innovation projects of Shandong province: study on competitive kinetics and mechanism of degradation of Geosmin and Humic Acid in water by UV/ $\mathrm{H}_{2} \mathrm{O}_{2}$ process, grant number:201603001.

Institutional Review Board Statement: Not applicable.

Informed Consent Statement: Not applicable.

Data Availability Statement: Data is contained within the article or supplementary material.

Acknowledgments: This work was financially supported by the National Major Science and Technology Projects: Evaluation and standardization for material and equipment of water supply system (2017ZX07501003); Evaluation and standardization of key technologies in operation and management of urban water supply system (2017ZX07501002); Special funds for postdoctoral innovation projects of Shandong province: study on competitive kinetics and mechanism of degradation of Geosmin and Humic Acid in water by $\mathrm{UV} / \mathrm{H}_{2} \mathrm{O}_{2}$ process (201603001).

Conflicts of Interest: We declare that we have no financial and personal relationships with other people or organizations that can inappropriately influence our work, there is no professional or other personal interest of any nature or kind in any product, service and/or company that could be construed as influencing the position presented in, or the review of, the manuscript entitled "Research About Organic Matter Removal and Biofilms Devel-opment of Pilot-Scale UV $/ \mathrm{H}_{2} \mathrm{O}_{2}$-BAC Process". 


\section{References}

1. Feng, M.J.; Zhang, Q.; Song, N.H. Occurrence Characteristics and Risk Assessment of Antibiotics in Source Water of the Nanjing Reach of the Yangtze River. Environ. Sci. 2019, 40, 5286-5293.

2. Zhang, Y.; Wang, J.; Lu, J.; Wu, J. Antibiotic resistance genes might serve as new indicators for wastewater contamination of coastal waters: Spatial distribution and source apportionment of antibiotic resistance genes in a coastal bay. Ecol. Indic. 2020, 114, 106299. [CrossRef]

3. He, Q.; Weng, H. Removal Effect of Taste and Odor for Chemical Preoxidation of Sunvim Water Plant in Gaomi. Environ. Sci. Technol. 2016, 36, 247-250.

4. Jia, R.B. Researches on algae change characteristics and influence factors in Yinhuang Reservoir. Ecol. Sci. 2013, 32, 757-762.

5. Han, L.; Liu, W.; Chen, M.; Zhang, M.; Fei, X. Comparison of NOM removal and microbial properties in up-flow/down-flow BAC filter. Water Res. 2013, 47, 4861-4868. [CrossRef] [PubMed]

6. Liu, C.; Olivares, C.I.; Pinto, A.J.; Lauderdale, C.V.; Brown, J.; Selbes, M.; Karanfil, T. The control of disinfection byproducts and their precursors in biologically active filtration processes. Water Res. 2017, 124, 630-653. [CrossRef]

7. Zhu, H.; Jia, R.; Sun, S.; Feng, G.; Wang, M.; Zhao, Q.; Xin, X.; Zhou, A. Elimination of trichloroanisoles by $\mathrm{UV}^{-} \mathrm{H}_{2} \mathrm{O}_{2}$ : Kinetics, degradation mechanism, water matrix effects and toxicity assessment. Chemosphere 2019, 230, 258-267. [CrossRef] [PubMed]

8. Du, Z.; Jia, R.; Li, C.; Cui, P.; Song, W.; Liu, J. Pilot-scale UV/ $\mathrm{H}_{2} \mathrm{O}_{2}-\mathrm{BAC}$ process for drinking water treatment-Analysis and comparison of different activated carbon columns. Chem. Eng. J. 2020, 382, 123044. [CrossRef]

9. Sun, Y.; Angelotti, B.; Brooks, M.; Dowbiggin, B.; Evans, P.J.; Devins, B.; Wang, Z.-W. A pilot-scale investigation of disinfection by-product precursors and trace organic removal mechanisms in ozone-biologically activated carbon treatment for potable reuse. Chemosphere 2018, 210, 539-549. [CrossRef]

10. Kim, W.H.; Nishijima, W.; Baes, A.U.; Okada, M. Micropollutant removal with saturated biological activated carbon (BAC) in ozonation-BAC process. Water Sci. Technol. 1997, 36, 283-298.

11. Weber, W.J., Jr. Preloading of GAC by natural organic matter in potable water treatment systems: Mechanisms, effects and design considerations. J. Water Supply Res. Technol. AQUA 2004, 53, 469-482. [CrossRef]

12. Liao, X.; Chen, C.; Wang, Z.; Wan, R.; Chang, C.; Zhang, X.; Xie, S. Pyrosequencing analysis of bacterial communities in drinking water biofilters receiving influents of different types. Process Biochem. 2013, 48, 703-707. [CrossRef]

13. Lohwacharin, J.; Phetrak, A.; Takizawa, S.; Kanisawa, Y.; Okabe, S. Bacterial growth during the start-up period of pilot-scale biological activated carbon filters: Effects of residual ozone and chlorine and backwash intervals. Process Biochem. 2015, 50, 1640-1647. [CrossRef]

14. Lautenschlager, K.; Hwang, C.; Ling, F.; Liu, W.T.; Boon, N.; Koester, O.; Egli, T.; Hammes, F. Abundance and composition of indigenous bacterial communities in a multi-step biofiltration-based drinking water treatment plant. Water Res. 2014, 62, 40-52. [CrossRef] [PubMed]

15. Lautenschlager, K.; Hwang, C.; Liu, W.T.; Boon, N.; Koester, O.; Vrouwenvelder, H.; Egli, T.; Hammes, F. A microbiology-based multi-parametric approach towards assessing biological stability in drinking water distribution networks. Water Res. 2013, 47, 3015-3025. [CrossRef]

16. Oh, S.; Hammes, F.; Liu, W.-T. Metagenomic characterization of biofilter microbial communities in a full-scale drinking water treatment plant. Water Res. 2018, 128, 278-285. [CrossRef] [PubMed]

17. Congcong, L. Study on Biofilm Characteristics of Biological Activated Carbon Filtration Process; Shandong Jianzhu University: Jinan, China, 2018.

18. Barai, A.; Guo, Y.; Mcgordon, A.; Jennings, P.A. Characterisation of aquatic humic and non-humic matter with size-exclusion chromatography-organic carbon detection-organic nitrogen detection (LC-OCD-OND). Water Res. 2011, 45, 879-885.

19. Li, X.; Rao, N.R.H.; Linge, K.L.; Joll, C.A.; Khan, S.; Henderson, R.K. An evaluation of measurement techniques for algal-derived organic nitrogen. Water Res. 2019, 165, 114998. [CrossRef]

20. Zhang, M.; Liu, W.; Nie, X.; Li, C.; Gu, J.; Zhang, C. Molecular analysis of bacterial communities in biofilms of a drinking water clearwell. Microbes Environ. 2012, 27, 443-448. [CrossRef]

21. Afzal, A.; Oppenländer, T.; Bolton, J.R.; El-Din, M.G. Anatoxin-a degradation by Advanced Oxidation Processes: Vacuum-UV at $172 \mathrm{~nm}$, photolysis using medium pressure UV and $\mathrm{UV} / \mathrm{H}_{2} \mathrm{O}_{2}$. Water Res. 2010, 44, 278-286. [CrossRef] [PubMed]

22. Rauf, M.A. Determination of opti-Muruganandhamm operating conditions of carmine decoloration by $\mathrm{UV} / \mathrm{H} 2 \mathrm{O} 2 \mathrm{using}$ response surfacemethodology. J. Hazard. Mater. 2009, 161, 281-286.

23. Stefan, M.I. Advanced Oxidation Processes for Water Treatment-Fundamentals and Applications; IWA Publishing: London, UK, 2018.

24. Ross, P.S.; van der Aa, L.T.J.; van Dijk, T.; Rietveld, L.C. Effects of water quality changes on performance of biological activated carbon (BAC) filtration. Sep. Purif. Technol. 2019, 212, 676-683. [CrossRef]

25. Han, L. The Characteristics and Application of Micro-Expansion Up-Flow Biological Activated Carbon Process; Tinghua University: Beijing, China, 2013.

26. Liang, C.H.; Chiang, P.C. Mathematical model of the non-steady-state adsorption and biodegradation capacities of BAC filters. J. Hazard. Mater. 2007, 139, 316-322. [CrossRef] [PubMed]

27. Mahvi, A.H. Application of response surface methodology for optimization of natural organic matter degradation by $\mathrm{UV} / \mathrm{H}_{2} \mathrm{O}_{2}$ advanced oxidation process. J. Environ. Health Sci. Eng. 2014, 12, 67. 
28. Chu, W.; Gao, N.; Yin, D.; Krasner, S.W.; Mitch, W.A. Impact of UV/ $\mathrm{H}_{2} \mathrm{O}_{2}$ Pre-Oxidation on the Formation of Haloacetamides and Other Nitrogenous Disinfection Byproducts during Chlorination. Environ. Sci. Technol. 2014, 48, 12190-12198. [PubMed]

29. Ding, S.; Wang, F.; $\mathrm{Chu}, \mathrm{W}$.; Chao, F. Using UV $/ \mathrm{H}_{2} \mathrm{O}_{2}$ pre-oxidation combined with an optimised disinfection scenario to control CX3R-type disinfection by-product formation. Water Res. 2019, 167, 115096. [CrossRef]

30. Marais, S.S.; Ncube, E.J.; Msagati, T.A.M.; Mamba, B.B.; Nkambule, T.T.I. Assessment of trihalomethane (THM) precursors using specific ultraviolet absorbance (SUVA) and molecular size distribution (MSD). J. Water Process Eng. 2019, 27, $143-151$.

31. Ates, N.; Kitis, M.; Yetis, U. Formation of chlorination by-products in waters with low SUVA-correlations with SUVA and differential UV spectroscopy. Water Res. 2007, 41, 4139-4148. [CrossRef]

32. Zheng, J.; Lin, T.; Chen, W.; Tao, H.; Tan, Y.; Ma, B. Removal of precursors of typical nitrogenous disinfection byproducts in ozonation integrated with biological activated carbon $\left(\mathrm{O}_{3} / \mathrm{BAC}\right)$. Chemosphere 2018, 209, 68-77. [CrossRef]

33. Conte, P.; Piccolo, A. Conformational arrangement of dissolved humic substances. Influence of solution composition on association of humic molecules. Environ. Sci. Technol. 1999, 33, 1682. [CrossRef]

34. Gibert, O.; Lefevre, B.; Fernandez, M.; Bernat, X.; Paraira, M.; Calderer, M.; Martinez-Llado, X. Characterising biofilm development on granular activated carbon used for drinking water production. Water Res. 2013, 47, 1101-1110. [CrossRef] [PubMed]

35. Moll, D.M.; Summers, R.S.; Fonseca, A.C.; Matheis, W. Impact of Temperature on Drinking Water Biofilter Performance and Microbial Community Structure. Environ. Sci. Technol. 1999, 33, 2377-2382. [CrossRef]

36. Silvana, V.; Markus, B.; Oliver, K.; Jakob, H.; Hans-Ulrich, W.; Frederik, H. Development of biomass in a drinking water granular active carbon (GAC) filter. Water Res. 2011, 45, 6347-6354.

37. Wang, F.; Halem, D.V.; Liu, G.; Lekkerkerker-Teunissen, K.; van der Hoek, J.P. Effect of residual $\mathrm{H}_{2} \mathrm{O}_{2}$ from advanced oxidation processes on subsequent biological water treatment: A laboratory batch study. Chemosphere 2017, 185, 637. [CrossRef] [PubMed]

38. Wang, Y.; Du, Z.; Liu, Y.; Wang, H.; Xu, F.; Liu, B.; Zheng, Z. The nitrogen removal and sludge reduction performance of a multi-stage anoxic/oxic (A/O) biofilm reactor. Water Environ. Res. 2019, 92, 94-105. [CrossRef]

39. Gerrity, D.; Arnold, M.; Dickenson, E.; Moser, D.; Sackett, J.D.; Wert, E.C. Microbial community characterization of ozonebiofiltration systems in drinking water and potable reuse applications. Water Res. 2018, 135, 207-219. [CrossRef] [PubMed]

40. Zhang, Y.; Cong, J.; Lu, H.; Li, G.; Qu, Y.; Su, X.; Zhou, J.; Li, D. Community structure and elevational diversity patterns of soil Acidobacteria. J. Environ. Sci. 2014, 26, 1717-1724. [CrossRef]

41. Wang, Y.; Liu, B.; Zhang, K.; Liu, Y.; Xu, X.; Jia, J. Investigate of in situ sludge reduction in sequencing batch biofilm reactor: Performances, mechanisms and comparison of different carriers. Front. Environ. Sci. Eng. 2018, 12, 1-15. [CrossRef]

42. Zhu, S.; Wu, H.; Wu, C.; Qiu, G.; Feng, C.; Wei, C. Structure and function of microbial community involved in a novel full-scale prefix oxic coking wastewater treatment O/H/O system. Water Res. 2019, 164, 114961-114963. [CrossRef]

43. Yang, H.; Yang, X.; Zhang, G.; Wang, B. Key Bacteria for the Microbial Degradation of Pollutants in Cellar Water. Environ. Sci. 2018, 39, 4766-4777. 